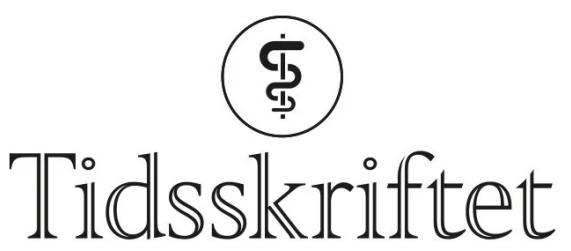

DEN NORSKE LEGEFORENING

\title{
Kvaliteten på medisinske obduksjonsrapporter
}

ORIGINALARTIKKEL

\section{HANNA MARIA ENG}

hanna_maria_e@hotmail.com

Avdeling for patologi

Akershus universitetssykehus

Nåværende arbeidssted:

Avdeling for patologi

Oslo universitetssykehus

Hun har bidratt til innsamling av data og evaluering/tolkning samt revisjon av manus.

Hanna Maria Eng er overlege.

Forfatteren har fylt ut ICMJE-skjemaet og oppgir ingen interessekonflikter.

\section{ROLF BRUUN BIE}

Avdeling for patologi

Sørlandet sykehus

Han har bidratt til innsamling av data og evaluering/tolkning samt revisjon av manus. Rolf Bruun Bie er avdelingsoverlege.

Forfatteren har fylt ut ICMJE-skjemaet og oppgir ingen interessekonflikter.

\section{ANNE JARSTEIN SKJULSVIK}

Avdeling for patologi

St. Olavs hospital

og

Institutt for klinisk og molekylær medisin

Norges teknisk-naturvitenskapelige universitet (NTNU)

Hun har bidratt til innsamling av data og evaluering/tolkning samt revisjon av manus.

Anne Jarstein Skjulsvik er overlege, ph.d., og førsteamanuensis.

Forfatteren har fylt ut ICMJE-skjemaet og oppgir ingen interessekonflikter.

\section{ANNE GRO PEDERSEN}

Dødsårsaksregisteret

Avdeling for helsedata og mottak

Folkehelseinstituttet i Bergen

Hun har bidratt til innsamling av data og evaluering/tolkning samt revisjon av manus.

Anne Gro Pedersen er cand.mag. i statsvitenskap og seniorrådgiver.

Forfatteren har fylt ut ICMJE-skjemaet og oppgir ingen interessekonflikter.

\section{GLENNY CECILIE ALFSEN}

Avdeling for patologi

Akershus universitetssykehus 
Hun har bidratt til innsamling av data og evaluering/tolkning samt revisjon av manus.

Glenny Cecilie Alfsen er førsteamanuensis emeritus.

Forfatteren har fylt ut ICMJE-skjemaet og oppgir ingen interessekonflikter.

\section{BAKGRUNN}

Medisinske obduksjoner er sjelden gjenstand for kvalitetssikring. Vi har undersøkt kvaliteten av obduksjonsrapporter i Norge og vurdert innvirkningen av feil på dødsårsaksstatistikken.

\section{MATERIALE OG METODE}

Hver femte medisinske obduksjonsrapport fra voksne (> 2 år) i 2014 ble gjennomgått. Obduksjonsresultatets betydning for registrering av dødsårsak ble undersøkt ved sammenligning av klinikers dødsmelding med koding i Dødsårsaksregisteret etter obduksjon.

\section{RESULTATER}

389 obduksjonsrapporter fra 15 patologiavdelinger ble unders $\varnothing$ kt. Obduksjonsbegjæring samt dødsmelding og dødsårsakskoder fra Dødsårsaksregisteret forelå for henholdsvis 339 og 360 kasus. Klinisk problemstilling forelå i 95 begjæringer, men ble kommentert av patolog i 33 tilfeller. Fedme ble sjelden oppgitt som et funn, selv ved sykelige avvik fra normalvekt. Postmortal virusunders økelse eller toksikologi var utført i henholdsvis 1 og 28 obduksjoner. Gjennomsnittlig svartid for obduksjoner uten og med nevropatologisk undersøkelse var henholdsvis 99 og 138 dager. Feil i oppsett av dødsårsak eller mangelfull rapportering forelå i 69 kasus (18 \%), hyppigst ved hjerte- og kardødsfall. Obduksjonssvaret medførte endret dødsårsak i Dødsårsaksregisteret i 206 av 36o (57\%) tilfeller med tilgjengelig kodedata. Feil i oppsett av obduksjonssvaret ga feil koding av dødsårsak i 22 av 47 (47\%) kasus med feil.

FORTOLKNING

Andelen obduksjonsrapporter med feil i oppsett av dødsårsak var uventet høy og kan ha konsekvenser for dødsårsaksstatistikken. Lange svartider på obduksjonene vanskeliggjør kommunikasjonen med kliniker om funn.

\section{HOVEDFUNN}

Kvaliteten på medisinske obduksjoner er preget av lange svartider og feil i oppsett av dødsårsak.

Median svartid for obduksjoner uten spesialundersøkelser eller hjerneundersøkelse var 99 dager, og 138 dager med slike undersøkelser.

Opp mot hver femte obduksjonsrapport hadde feil i oppsett eller manglet dødsårsak, med påfølgende feil koding av dødsårsak i Dødsårsaksregisteret i 47 \% av tilfellene.

Synkende obduksjonsfrekvens er en kjent trend internasjonalt (므). I 1980-årene ble det utført rundt 6 ooo medisinske obduksjoner årlig i Norge, noe som tilsvarte ca. $15 \%$ av alle dødsfall (ㅁ). I 2018 var antallet medisinske obduksjoner 1397, eller $3 \%$ av alle dødsfall (3,4.). I en spørreundersøkelse fra 2017 om obduksjonspraksis i Europa ble bedre diagnostiske metoder og liten interesse fra patologer og klinikere angitt som mulige årsaker til synkende obduksjonstall (5). Det er nærliggende å spørre om også kvaliteten av obduksjonene kan være en faktor for synkende obduksjonsfrekvens. 
Som medlem av Verdens helseorganisasjon (WHO) er Norge forpliktet til å føre offisiell dødsårsaksstatistikk ved bruk av et internasjonalt sykdomsklassifikasjonssystem (International classification of diseases, ICD) $(\underline{6}$, .7.). Dødsårsak angis av kliniker ved hjelp av Legeerklæring om dødsfall (dødsmelding) og føres som underliggende dødsårsak (avsnitt $1 \mathrm{a}-\mathrm{d}$ i dødsmeldingen) og eventuelt medvirkende dødsårsaker (avsnitt 2). I henhold til Forskrift om innsamling og behandling av helseopplysninger i Dødsårsaksregisteret (Dødsårsaksregisterforskriften) skal funn ved obduksjon føres på samme måte som ved utfylling av dødsmelding ( $\underline{8})$. Det skilles mellom to typer obduksjoner: Rettslige obduksjoner begjæres av påtalemyndighet som ledd i etterforsking, og medisinske obduksjoner begjæres av lege som ledd i kvalitetssikring av medisinsk virksomhet og undervisning. Medisinske obduksjoner i Norge utføres av spesialister i patologi eller leger under opplæring i spesialiteten. Formatet for rapporteringen av medisinske obduksjoner i Norge har vært uendret i mange tiår og følger samme mønster i hele landet (se ramme 1).

\section{Ramme 1 Format av den medisinske obduksjonsrapporten}

\section{Klinisk sykehistorie og problemstilling}

Fra obduksjonsbegjæring og/eller klinisk journal.

\section{Ytre undersøkelse}

Kjønn, vekt, lengde, særlige kjennetegn, arr, tegn til sykdom, skader og lignende.

\section{Indre undersøkelse}

Makroskopisk beskrivelse av hulrom, kar, indre organer (inkludert form og vekt).

Mikroskopisk undersøkelse av vev fra hjerte, lunge, lever og nyre (standard), samt fra andre områder med mistenkt patologi.

Eventuelle tilleggsundersøkelser: bakteriologi, virologi, toksikologi, genetikk.

\section{Oppsett av funn, som regel på første side}

1 a-d: Dødsårsak som sekvens, fra umiddelbar til underliggende.

2: Medvirkende sykdom/sykdommer.

Bifunn: Sykdommer eller funn uten betydning for dødsprosessen.

Vurdering: Diskusjon av funn, rettet mot kliniker.

Obduksjonsrapportenes første side oversendes Dødsårsaksregisteret, som sammenholder funnene med original dødsmelding og korrigerer dødsårsaken om nødvendig. Obduksjonsresultatet utgjør således en viktig del av datagrunnlaget i dødsårsaksstatistikken $(9, \underline{10})$.

Obduksjon fremheves ofte som gullstandard for morfologisk diagnostikk og dødsårsak, uten at det eksisterer noen systematisk kvalitetskontroll av denne delen av medisinsk virksomhet (11). Vi ønsket derfor å undersøke kvaliteten på obduksjonsrapportene i Norge, både med hensyn til innhold, oppsett av funn og svartider. Videre ønsket vi å undersøke hvordan feil oppsett av dødsårsak virket inn på dødsårsaksstatistikken.

\section{Materiale og metode}

Hver femte obduksjonsrapport på døde eldre enn to år (voksenobduksjon) i perioden 1.1.31.12.2014 ble innkalt fra patologiavdelingene i Norge. Før avidentifisering registrerte man avdødes kjønn og alder, type sykehus hvor obduksjonen var utført (universitetssykehus eller ikke) og svartid definert som tid mellom dato for obduksjon og signering av endelig rapport. En prosjektgruppe på tre patologer med erfaring fra obduksjonspatologi (HME, 
RBB, AJS) roterte obduksjonsrapportene seg imellom i to runder og registrerte om disse inneholdt tilstrekkelige kliniske opplysninger til å forstå sykdomsforløpet, data fra utvendig og innvendig undersøkelse, mikroskopi og tilleggsundersøkelser som toksikologi, mikrobiologi, og genetiske undersøkelser. Kroppsmasseindeks (KMI) ble utregnet om mulig (12). Ved evaluering av obduksjonsrapportene hadde ikke gruppen tilgang på kliniske opplysninger utover de som var referert i obduksjonsrapportene og/eller i obduksjonsbegjæringene. Prosjektgruppen vurderte feil i oppsett av funn, både i forhold til ICD/WHO-regelverket og innholdet i rapportene, og kategoriserte disse i 1) feil i årsaksrekken av underliggende dødsårsak i avsnitt $1 \mathrm{a}-\mathrm{d}, 2$ ) feil plassering av underliggende dødsårsak som medvirkende sykdom i avsnitt 2 eller som bifunn, 3) oppføring av flere uavhengige sykdommer som underliggende dødsårsak, 4) oppføring av underliggende dødsårsak flere steder, for eksempel både som underliggende og medvirkende sykdom, 5) manglende underliggende dødsårsak, 6) mors subita, «plutselig død» eller lignende uttrykk uten kobling til spesifikk sykdom, og 7 ) generelt mangelfulle rapporter uten pålitelig dødsårsak. Om det forelå en vurdering av funnene ble også registrert.

Alle kasus hvor det var uenighet om kategorisering av feil ble diskutert i felleskap for konsensus. Kopi av dødsmelding og endelig koding av dødsårsak (kodestreng) etter eventuell korreksjon ved hjelp av obduksjonsresultatet ble innkalt fra Dødsårsaksregisteret og sammenlignet med innhold og oppsett av dødsårsak i obduksjonsrapportene.

Studien er godkjent av Personvernombudet ved Akershus universitetssykehus (16 - 106) og Regionale komiteer for medisinsk og helsefaglig forskningsetikk (REK) (2016/619). Konsesjon til å behandle helseopplysninger er innhentet fra Datatilsynet (16/o1121 - 2/SBO).

\section{Resultater}

Til sammen 389 medisinske obduksjonsrapporter ble tilsendt fra 15 patologiavdelinger.

Antall rapporter utgjorde $23 \%$ av medisinske voksenobduksjoner i 2014 (13).

Obduksjonsbegjæringer var tilgjengelig for 339 obduksjonsrapporter. For de resterende 50 obduksjonsrapportene var obduksjonsbegjæringene ikke vedlagt og var kun tilgjengelig i den enkelte institusjons kliniske journal. Obduksjonsaktiviteten var størst ved universitetssykehusene (tabell 1). Flertallet av de obduserte var menn (62\%). Median alder var 75 år for kvinner og 70 år for menn. 59 (15\%) av obduksjonene var fra dødsfall utenfor sykehusene. Andelen obduksjoner utenfra var større ved andre sykehus enn ved universitetssykehus (henholdsvis $23 \%$ og $12 \%$ ).

\section{Tabell 1}

Obduksjonsrapporter for døde eldre enn to år fra 2014 fordelt på type sykehus, kjønn og alder $(\mathrm{n}=389)$.

\begin{tabular}{|c|c|c|c|}
\hline & Totalt & $\begin{array}{l}\text { Universitetssykehus, n } \\
=6\end{array}$ & $\begin{array}{l}\text { Andre sykehus, } \\
\mathrm{n}=\mathbf{9}\end{array}$ \\
\hline Antall rapporter (spredning) & 389 & $270(17-71)$ & $119(4-21)$ \\
\hline Antall menn (\%) & $241(62)$ & $171(63)$ & $70(59)$ \\
\hline \multicolumn{4}{|l|}{ Median alder (spredning) } \\
\hline Menn & $70(21-93)$ & $71(21-93)$ & $68(25-93)$ \\
\hline Kvinner & $75(16-98)$ & $74(16-98)$ & $75(42-93)$ \\
\hline
\end{tabular}


Problemstilling fra kliniker forelå i 95 av 339 obduksjonsbegjæringer og var ofte formulert som ønske om å bekrefte/avkrefte lungeemboli, hjerteinfarkt eller blødning. Av disse ble den kliniske problemstillingen forsøkt besvart $\mathrm{i} 33$ obduksjonsrapporter. I de øvrige 244 begjæringene var ønsket om obduksjon begrunnet med «Dødsårsak?» eller lignende.

Seks obduksjonsrapporter inneholdt ingen sykehistorie. Resultat av premortale laboratorieundersøkelser og medikamentbruk var angitt i henholdsvis 225 og 153 tilfeller.

YTRE OG INDRE UNDERS ØKELSE

Ytre funn og dødstegn var kommentert i henholdsvis 284 og 311 rapporter. Kroppsmasseindeks var utregnet i 41 rapporter. Undervekt $(\mathrm{KMI}<18,5)$ var aldri inkludert i diagnoseoppsettene. Fedme (KMI $\geq 30$ ) var angitt som diagnose i 7 av 85 kasus og i 3 av 10 med KMI > 40. Overvekt var også sjelden angitt som diagnose i dødsmeldinger eller i kodestrenger fra Dødsårsaksregisteret (henholdsvis 5 og 9 av 360 ), og aldri som underliggende dødsårsak.

De fleste organer og organsystemer var adekvat beskrevet, med unntak for sidespesifisering av lunge- og nyrevekt, som forelå i henholdsvis 103 og 183 rapporter, og lokalisering $\mathrm{i}$ organene av sykelige funn. Lokalisering av sykelige funn i hjerte og lunger var angitt i henholdsvis 96 og 79 kasus.

Hjernen ble undersøkt i 338 obduksjoner. Unders $\emptyset$ kelsene ble foretatt på ufikserte hjerner uten mikroskopering i mer enn halvparten av tilfellene (190 av 338). Mikroskopering ble ikke utført i 26 av 148 fikserte hjerner.

TILLEGGSUNDERS $\varnothing$ KELSER

Bruk av tilleggsundersøkelser ved obduksjonene varierte, også i tilfeller av dødsfall utenfor sykehus hvor kliniske opplysninger ofte var sparsomme. Postmortal bakteriologisk eller toksikologisk undersøkelse var angitt i henholdsvis 88 og 28 rapporter, mens virus (influensa) var undersøkt i ett tilfelle. Det var ingen tilfeller av genetisk unders $\emptyset$ kelse.

\section{MORS SUBITA}

Mors subita, «plutselig død» eller lignende ble angitt som dødsårsak i 13 obduksjonsrapporter. Fem av disse ble vurdert av prosjektgruppen som ikke korrekt, uten kobling mot sykdom og uten diskusjon av annen mulig forklaring.

\section{VURDERING}

En nærmere forklaring av oppsettet av funnene eller kommentering av kliniske spørsmålsstillinger forelå i 329 av 389 rapporter. I 91 av disse ga teksten ingen tilleggsinformasjon ut over det som allerede framgikk av oppsettet.

SVARTID

Gjennomsnittlige svartider uten eller med nevropatologisk undersøkelse var på henholdsvis 99 og 138 dager. Lengste svartid uten nevropatologi var 203 dager, med nevropatologi 345 dager. Det var ingen vesentlig forskjell i svartider mellom patologiavdelinger ved universitetssykehus og andre sykehus.

\section{UNDERLIGGENDE DØDSÅSAK}

Oppsett av funn med dødsårsak i henhold til Verdens helseorganisasjon ble hyppigst vurdert som korrekt i obduksjoner med spørsmål om malign sykdom eller lungesykdommer (tabell 2). Hver femte dødsårsak ved dødsfall med hjerte- og karproblematikk ble vurdert som feil satt opp. Samlet ble det påvist feil eller manglende dødsårsak i opp mot hver femte rapport (69av 389).

\section{Tabell 2}

Underliggende dødsårsak i obduksjonsrapporter for døde eldre enn to år fra 2014 ( $(n=389)$, vurdert ut fra Verdens helseorganisasjons regelverk for oppsett og innhold. 


\begin{tabular}{|c|c|c|c|c|}
\hline & & $\begin{array}{l}\text { Oppsett av } \\
\text { underliggend } \\
\text { dødsårsak }\end{array}$ & & \\
\hline Type sykdom & $\begin{array}{l}\text { Totalt } \\
\text { antall }\end{array}$ & Korrekt & Ukorrekt & $\begin{array}{l}\text { Mangelfulle } \\
\text { rapporter }\end{array}$ \\
\hline Malign sykdom & 95 & 92 & 3 & 0 \\
\hline Hjerte- og karsykdom ${ }^{1}$ & 140 & 105 & 30 & 5 \\
\hline Lungesykdom² & 16 & 13 & 3 & 0 \\
\hline Infeksjon ${ }^{3}$ & 52 & 40 & 9 & 3 \\
\hline Annen sykdom 4 & 68 & 57 & 9 & 2 \\
\hline Unaturlig årsak ${ }^{5}$ & 18 & 13 & 3 & 2 \\
\hline Sum & 389 & 320 & 57 & 12 \\
\hline
\end{tabular}

${ }^{1}$ Inkludert lungeemboli og aneurisme.

${ }^{2}$ Inkludert lungeemfysem/kols og lungefibrose.

${ }^{3}$ Inkludert endokarditt, divertikulitt og pankreatitt.

${ }^{4}$ Inkludert alkohol, diabetes, ulcus, amyloidose, demens og multippel sklerose.

5Inkludert ulykke, snøskred, fall, hengning og forgiftning.

Type feil er nærmere angitt i tabell 3. Dødsårsaken var nevnt, men på feil sted i oppsettet i 30 kasus (feilkategori 1-4). De øvrige rapportene som ble vurdert som feil (feilkategori 5-6) var enten uten angitt eller sikker dødsårsak. Det var ingen vesentlig forskjell mellom universitetssykehus og andre sykehus i type feilkategorier. Seks kasus var ikke strukturert i henhold til dødsårsaksregisterforskriften og kunne derfor ikke kategoriseres. Tolv obduksjonsrapporter ble kategorisert som mangelfulle med så store mangler i innhold for øvrig at de ikke ble vurdert med henblikk på oppsett og koding.

\section{Tabell 3}

Antall obduksjonsrapporter som ble vurdert til ikke å ha korrekt oppsett av underliggende dødsårsak og antall med påfølgende feilkoding i Dødsårsaksregisteret basert på et utvalg av obduksjonsrapporter fra $2014(n=371)$. Seks rapporter uten bruk av regelverket til Verdens helseorganisasjon og tolv mangelfulle rapporter er ikke inkludert.

\begin{tabular}{|c|c|c|c|}
\hline Type feil & Eksempel & $\begin{array}{l}\text { Feil oppsett i } \\
\text { obduksjonsrapport }\end{array}$ & $\begin{array}{l}\text { Påfølgende feil } \\
\text { koding av dødsårsak }\end{array}$ \\
\hline $\begin{array}{l}\text { Feil i årsaksrekken } \\
\text { av underliggende } \\
\text { dødsårsak } 1 \text { a-c }\end{array}$ & $\begin{array}{l}1 \mathrm{a} \text { : Akutt hjerteinfarkt } \\
1 \mathrm{~b}: \\
\text { Koronaraterosklerose } \\
1 \mathrm{c}: \text { Kols }\end{array}$ & 8 & 3 \\
\hline $\begin{array}{l}\text { Underliggende } \\
\text { dødsårsak plassert } \\
\text { på II eller på bifunn }\end{array}$ & $\begin{array}{l}\text { la: Pneumoni } \\
\text { II eller bifunn: } \\
\text { Langtkommet multippel } \\
\text { sklerose }\end{array}$ & $10^{1}$ & 6 \\
\hline
\end{tabular}




\begin{tabular}{|c|c|c|c|}
\hline Type feil & Eksempel & $\begin{array}{l}\text { Feil oppsett i } \\
\text { obduksjonsrapport }\end{array}$ & $\begin{array}{l}\text { Påfølgende feil } \\
\text { koding av dødsårsak }\end{array}$ \\
\hline $\begin{array}{l}\text { Flere uavhengige } \\
\text { sykdommer oppført } \\
\text { som underliggende } \\
\text { dødsårsak }\end{array}$ & $\begin{array}{l}\text { la: Hjerte med infarkt, } \\
\text { aortastenose og } \\
\text { amyloidose }\end{array}$ & 12 & 3 \\
\hline $\begin{array}{l}\text { Underliggende } \\
\text { dødsårsak oppført } \\
\text { både som } \\
\text { underliggende og } \\
\text { bidragsytende } \\
\text { sykdom }\end{array}$ & $\begin{array}{l}\text { la: Hjerte med ferskt } \\
\text { infarkt } \\
\text { lb: Uttalt } \\
\text { koronaraterosklerose } \\
\text { II: Hjerte med gammelt } \\
\text { infarkt }\end{array}$ & $-^{2}$ & - \\
\hline $\begin{array}{l}\text { Underliggende } \\
\text { dødsårsak } \\
\text { fremkommer ikke }\end{array}$ & Ia: Peritonitt & 13 & 9 \\
\hline $\begin{array}{l}\text { Mors subita, uten } \\
\text { kobling til antatt } \\
\text { underliggende } \\
\text { dødsårsak }\end{array}$ & $\begin{array}{l}\text { la: Mors subita } \\
\text { II eller bifunn: uttalt } \\
\text { aterosklerose }\end{array}$ & $4^{1}$ & 1 \\
\hline Sum & & 47 & 22 \\
\hline
\end{tabular}

${ }^{1}$ Kodestreng ikke mottatt for ett kasus
${ }^{2}$ Kodestreng ikke mottatt for to kasus

\section{BETYDNING FOR DØDSÅRAKSSTATISTIKKEN}

Kopi av original dødsmelding og tilhørende kodestreng fra dødsårsaksregisteret forelå for 360 av 389 dødsfall. Sammenligning mellom original dødsmelding og endelig koding av dødsfallet i Dødsårsaksregisteret viste endring som følge av obduksjon i 206 tilfeller (57\%). I 140 tilfeller medførte obduksjonsresultatet endring av hovedkapittel av dødsårsak i ICD10, eksempelvis fra infeksjonssykdom til hjerte- og karsykdom, mens $66 \mathrm{~d} \emptyset \mathrm{dsfall}$ fikk endret underkapittel.

WHO-regelverket sikret riktig koding av obduksjonsresultatet i mange tilfeller med feil i oppsett av underliggende dødsårsak (tabell 3). Feil plassering av underliggende dødsårsak som medvirkende eller som bifunn ga større andel feilkodinger (kategori 2-feil). At 4 av 13 kasus uten angitt dødsårsak og 3 av 4 med «mors subita» ble kodet korrekt, skyldtes at Dødsårsaksregisteret etter mottak av obduksjonsresultatet innhentet tilleggsopplysninger. Samlet resulterte nesten halvparten av obduksjonene med feil oppsett av dødsårsak i gal koding i offentlig statistikk.

\section{Diskusjon}

Obduksjon er en medisinsk undersøkelse som ofte fremheves som gullstandarden for å finne dødsårsak. Samtidig er det forbausende lite fokus på kvalitetssikring av selve metoden og få studier. En nord-amerikansk studie så bare på informasjon på rapportenes forsider og konkluderte med behov for standardisering (144.). En mer detaljert studie fra Storbritannia av rettslige likundersøkelser konkluderte med at kvaliteten var dårlig eller uakseptabel hos $25 \%$ (15).

Det er viktig å presisere at vår studie ikke sier noe om kvaliteten på utføringen av selve obduksjonen, men kun omhandler rapporteringen. Vår gjennomgang av medisinske obduksjoner viser at de fleste rapportene inneholdt tilstrekkelige beskrivelser av funn, 
men hadde større mangler når det gjaldt adressering av klinikers spørsmål, dødsårsaker og svartider.

En spesifisert problemstilling fra rekvirenten ble bare direkte besvart i en tredel av tilfellene. Manglende kommentering av spesifikke spørsmål kan grunnes i at problemstillingene fra klinikere anses som standardfraser, men også skyldes lang svartid, med lite fokus på rekvirenten når rapporten endelig skrives. De fleste obduksjoner gjennomføres innen få dager, forutsatt at kliniker har fylt ut begjæringen om obduksjon. Selve obduksjonen tar bare få timer. Fremføringen av prøver til mikroskopi behøver ikke ta lenger tid enn for annen vevsdiagnostikk, med opp mot en uke før snittene kan granskes og rapporten ferdigstilles. Lang tid fra obduksjonen er utført til funnene er sammenfattet og rapporten utsendt er et velkjent problem også internasjonalt $(\mathbf{1 5}, \underline{16})$. Vår unders $\varnothing$ kelse viste svartider langt over det som er anbefalt i retningslinjer fra Den norske patologforening (DNP), der svartider på henholdsvis to og åtte uker ved obduksjoner uten og med nevropatologi anbefales (17.). Lange svartider kan vitne om manglende fokus i patologiavdelingene på obduksjonens betydning, med prioritering av diagnostisering av prøver fra levende framfor de døde, samt gjenspeile et kapasitetsproblem innen deler av patologien, ikke minst innen nevropatologi. En omorganisering av patologiavdelingen kortet svartidene vesentlig ned i en studie ved universitetssykehuset i Bergen (묘).

Obduksjonens betydning har endret seg. Fra et opprinnelig fokus på patologisk/anatomiske funn, har betydningen av å vurdere funn i sammenheng med klinikk fått større plass (19.). Uten kjennskap til sykehistorien og uten å inkludere det kliniske bildet, vil mange typer dødsårsaker kunne underkjennes i obduksjonsrapportene og dermed også i dødsårsaksstatistikken. Manglende inklusjon av kliniske funn og lite bruk av tilleggsundersøkelser ved obduksjonen kan være årsaken til at blant annet psykiatriske tilstander eller sukkersyke som underliggende årsaker til sykdom eller død underrapporteres av patologer (므). Vår undersøkelse viser også at et tydelig makroskopisk funn som fedme tillegges liten betydning, til tross for at dette er en potensielt dødelig tilstand. Følgene for overvåking av folkehelse og fedmeepidemi gjennom

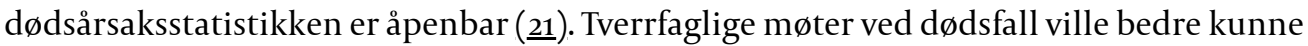
sikre at relevante opplysninger vurderes i rapportene og bidra til å bedre kommunikasjonen med kliniker.

Det eksisterer ingen retningslinjer for bruken av tilleggsundersøkelser ved medisinske obduksjoner. Spesielt toksikologiske undersøkelser kan være av stor verdi ved dødsfall med lite eller manglende kliniske opplysninger. Lav andel toksikologiske undersøkelser kan skyldes høye kostnader (22). Manglende tilleggsunders $\emptyset$ kelser på virus antyder en underrapportering av virusinduserte infeksjonssykdommer.

Obduksjonsrapportene i vår studie er fra 2014, men det har ikke skjedd endringer i medisinsk obduksjonspraksis i Norge før eller etter denne perioden. Det er således ingen grunn til å tro at obduksjonsrapportene fra 2014 ikke gjenspeiler virksomheten også i dag.

Sammenligningen av obduksjonsfunnene i vår studie opp mot dødsårsaksstatistikken bekreftet at obduksjon er et viktig korrektiv ved fastsetting av dødsårsak, med endret koding i over halvparten av kasus. Dette er også påpekt av andre (22, 23). På grunn av seleksjon av vanskelige kasus ved lave obduksjonsfrekvenser, er andelen på $57 \%$ endrede dødsårsakskoder sannsynligvis unaturlig høy.

Nesten hver femte obduksjonsrapport hadde feil underliggende dødsårsak. WHOregelverkets algoritmer benyttet av Dødsårsaksregisteret fanger opp de mest åpenbare feilene i dødsårsaksoppsettene, og ikke alle typer feil er derfor like kritiske for statistikken (24).). I eksempelet på kategori 1-feil i tabell 3 ville algoritmene for eksempel hindret feilkoding gjennom gjenkjenning av et ulogisk ledd fra $1 \mathrm{c}$ til $1 \mathrm{~b}$ (kols fører ikke til koronaraterosklerose). Likevel medførte feilene gal koding i dødsårsaksstatistikken for nær halvparten av de feilaktige rapportene. Lav obduksjonsfrekvens gjør at dårlig kvalitet på obduksjonsrapportene har liten innflytelse på den nasjonale dødsårsaksstatistikken i dag. 
Feilraten bekrefter imidlertid at det er behov for bedre kunnskaper om føring av funn og dødsårsaker blant patologene. Et generelt lavt antall medisinske obduksjoner har medført reduserte krav i spesialistutdannelsen, noe som kan forverre kompetansen ytterligere (5). Medisinske obduksjoner utføres av leger i spesialisering og spesialister i patologi. For å bedre kvaliteten har man i Storbritannia omgjort medisinsk obduksjonsvirksomhet til en subspesialitet (25). Også i Nederland, Tyskland og USA har behovet for obduksjon som eget

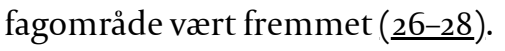

Rettslige obduksjonsrapporter blir kvalitetssikret av den Rettsmedisinske kommisjon (29).). Et tilsvarende organ for medisinske obduksjoner har vært foreslått tidligere, men ikke gjennomført (3ㅇ) $)$ Vår studie underbygger at det fortsatt er behov for en systematisk kvalitetskontroll av medisinsk obduksjonsvirksomhet.

\section{KONKLUSJON}

Det er behov for økt fokus på kvaliteten på medisinske obduksjonsrapporter. Å sikre kunnskap blant patologer om oppsett av funn og dødsårsaker etter medisinske obduksjoner, samt bedre kommunikasjon med kliniker, inklusive tiltak for bedring av svartider, vil være gode bidrag.

Artikkelen er fagfellevurdert.

\section{LITTERATUR}

1. Geller SA. A short history of human dissection and the autopsy. I: Hooper J, Williamson AK, red. Best practices and future directions. Springer International Publishing AG, 2018:3-16.

2. Den norske patologforening, Grafisk fremstilling i nettkurs: Dødsattester, Den norske legeforening. https://nettkurs.legeforeningen.no/course/view.php?id=113 Lest 5.10.2020.

3. Den norske patologforening. Årsmeldinger. Aktivitetstall 2018. https://www.legeforeningen.no/globalassets/foreningsledd/fagmedisinske-foreninger/den-norskepatologforening/aktivitetstall-dnp-2018-samlet.xls Lest 10.06.2020.

4. Folkehelseinstituttet. Dødsårsaksregisteret - statistikkbank. http://statistikkbank.fhi.no/dar/ Lest 10.6.2020.

5. Alfsen GC, Pontinha CM. Autopsies in Europe. A survey from the European Society of Pathology (ESP). https://www.esp-

pathology.org/_Resources/Persistent/554897c61e3648ea976f1405d337ofocc3ceb9d7/Survey\%2oAutopsy \%20in\%2oEurope.pdf Lest 2.3.2020.

6. Folkehelseinstituttet. Slik kodes og kvalitetssikres dødsårsaker i Dødsårsaksregisteret. https://www.fhi.no/hn/helseregistre-og-registre/dodsarsaksregisteret/dodsarsaken-kodes-med-icdkoder/ Lest 10.6.2020.

7. International Statistical Classification of Diseases and Health Related Problems. ICD-10. https://icd.who.int/browse10/2015/en Lest 10.6.2020.

8. FOR-2001-12-21-1476. Forskrift om innsamling og behandling av helseopplysninger i Dødsårsaksregisteret (Dødsårsaksregisterforskriften). https://lovdata.no/dokument/SF/forskrift/2oo112-21-1476?q=d\%C3\%B8ds\%C3\%A5rsaksregister Lest 10.6.2020.

9. Folkehelseinstituttet. Dødelighet og dødsårsaker i Norge gjennom 6o år-1951-2010. Rapport 2012:4. https://www.fhi.no/globalassets/dokumenterfiler/helseregistre/dar/dodelighet-ogdodsarsaker-pdf.pdf Lest 27.11.2020.

10. NOU 2011:21. Når døden tjener livet.

https://www.regjeringen.no/contentassets/b92d14d928b3427398cgfo4foof2002f/no/pdfs/nou201120110 o210oodddpdfs.pdf Lest 28.10.2020.

11. Goldman L, Sayson R, Robbins S et al. The value of the autopsy in three medical eras. N Engl J Med 1983; 308: 1000-5. [PubMed][CrossRef] 
12. World Health Organization. Regional office for Europe. Body Mass Index - BMI.

https://www.euro.who.int/en/health-topics/disease-prevention/nutrition/a-healthy-lifestyle/bodymass-index-bmi Lest 2.3.2020.

13. Den norske patologforening. Aktivitetstall 2014.

https://www.legeforeningen.no/globalassets/foreningsledd/fagmedisinske-foreninger/den-norskepatologforening/aktivitetstall-dnp-2014.xls Lesthttp://10.6.2020.

14. Baker PB, Zarbo RJ, Howanitz PJ. Quality assurance of autopsy face sheet reporting, final autopsy report turnaround time, and autopsy rates: a College of American Pathologists Q-Probes study of 10003 autopsies from 418 institutions. Arch Pathol Lab Med 1996; 120: 1003-8. [PubMed]

15. Lucas SB, Cooper H, Emmett S et al. The coroner's autopsy: do we deserve better? A report of the National Confidential Enquiry into Patient Outcome and Death. London: National Confidential Enquiry into Patient Outcome and Death, 2006.

https://www.ncepod.org.uk/2006Report/Downloads/Coronial\%20Autopsy\%2oReport\%202006.pdf Lest 7.10.2020

16. Siebert JR. Increasing the efficiency of autopsy reporting. Arch Pathol Lab Med 2009; 133: 1932-7. [PubMed][CrossRef]

17. Den norske patologforening. Veileder i obduksjon, voksne.

https://www.legeforeningen.no/contentassets/64927532ado3493c801962cca192od4o/dokument-2organisering-av-obduksjonstjenesten.pdf Lest 7.10.2020.

18. Berget E, Ramnefjell M, Svendsen EB et al. Færre sykehusobduksjoner-lang svartid. Tidsskr Nor Laegeforen 2007; 127: 2800-2. [PubMed]

19. Diallo-Danebrock R, Abbas M, Groß D et al. Geschichte der anatomischen und klinischen Obduktion. Pathologe 2019; 40: 93-100. [PubMed][CrossRef]

20. Alfsen GC. Medisinsk obduksjon ved dødsfall utenfor sykehus. Tidsskr Nor Legeforen 2013; 133: 756-9. [PubMed][CrossRef]

21. Forebygging, utredning og behandling av overvekt og fedme hos voksne. Nasjonale faglige retningslinjer IS-1735. Oslo: Helsedirektoratet, 2010.

https://www.helsedirektoratet.no/retningslinjer/overvekt-og-fedme-hos-

voksne/Overvekt\%20og\%2ofedme\%2ohos\%2ovoksne\%20\%E2\%80\%93\%2oNasjonal\%2ofaglig\%2oretningsl inje\%2ofor\%2oforebygging,\%2outredning\%2oog\%2obehandling.pdf/_/attachment/inline/24ec824b646d-4248-951f-

db6b867ce6cb:4eo740b933ffd5bco3c8fofdcaboob4135fe4ae9/Overvekt\%2oog\%2ofedme\%2ohos\%2ovoks ne\%20\%E2\%80\%93\%20Nasjonal\%2ofaglig\%2oretningslinje\%2ofor\%2oforebygging,\%2outredning\%2oog\% 2obehandling.pdf Lest 29.4.2021.

22. Alfsen GC, Mæhlen J. Obduksjonens betydning for registrering av dødsårsak. Tidsskr Nor Legeforen 2012; 132: 147-51. [PubMed][CrossRef]

23. Illing G, Lessig R, Stang A. Analyse der Kodierungsqualität der Leichenschauscheine und Obduktionsraten in Chemnitz, 2010-2013. Gesundheitswesen 2020; 82:354-6o. [PubMed][CrossRef]

24. Johansson LA, Pavillon G. IRIS: A language-independent coding system based on the NCHS system MMDS. Tokyo: Who-Fic Network Meeting, 2005.

https://apps.who.int/classifications/apps/icd/meetings/tokyomeeting/B_6-

2\%20IRIS\%20A\%2olanguage\%2oindependent\%2ocoding\%2osystem.pdf Lest 29.9.2020.

25. The Royal College of Pathologists. Examination regulations 2020. Royal College Higher Autopsy training module. 2019. https://www.rcpath.org/uploads/assets/cbbob46b-2C40-475abc4afa382f74ddca/c3214c72-8281-4f5c-897f31faze2cbdf7/Autopsy-Regulations-and-Guidelines.pdf Lest 7.10.2020.

26. van den Tweel JG, Wittekind C. The medical autopsy as quality assurance tool in clinical medicine: dreams and realities. Virchows Arch 2016; 468: 75-81. [PubMed][CrossRef]

27. Erlmeier F, Weichert W, Knüchel R et al. Erwachsenenobduktionen im letzten Jahrzehnt in Deutschland : Daten zweier Universitätskliniken. Pathologe 2017;38: 430-7. [PubMed][CrossRef]

28. Williamson AK. Evolving autopsy practice models. I: Hooper J, Williamson AK, red. Autopsy in the 21st century. Best practices and future directions. Springer International Publishing AG, 2018: 57-76.

29. Statens sivilrettforvaltning. Den rettsmedisinske kommisjon. https://www.sivilrett.no/denrettsmedisinske-kommisjon.304199.no.html Lest 4.11.2020.

30. Patologifaget i det norske helsevesen. Med pasientens liv og helse under mikroskopet. Statens helsetilsyns utredningsserie 1999:2.

https://www.helsetilsynet.no/globalassets/opplastinger/publikasjoner/utredningsserien/patologifag _norsk_helsevesen_ik-2682.pdf Lest 29.4.2021. 
Publisert: 16. august 2021. Tidsskr Nor Legeforen. DOI: 10.4045/tidsskr.20.10oo

Mottatt 3.12.2020, første revisjon innsendt 10.1.2021, godkjent 29.4.2021.

Publisert under åpen tilgang CC BY-ND. Lastet ned fra tidsskriftet.no 26. april 2023. 